\title{
Ocsút a búzától
}

\section{Recenzió a Mútárgyhamisítás magyar szemmel. Ocsút a búzától ${ }^{1}$ címü könyvröl}

\section{FENYVESI Csaba² - HORVÁTH Orsolya ${ }^{3}$}

A Pécsi Tudományegyetem Állam- és Jogtudományi Karán „Kriminalisztika és művészetek” címmel évek óta szabadon választott tantárgyat hirdetünk joghallgatóknak, akiknek töretlen a téma iránti lelkesedése.

Emellett a Magyar Tudományos Akadémia Pécsi Akadémiai Bizottságán belül működik egy Bűnügyi Tudományok Munkabizottsága, amely - az universitas szellemében - 2017 októberében a „Büntetőeljárás a festészetben” címmel szervezett tudományos ülést, amelyen büntetőjogászok értekeztek közösen egy esztéta kollégával a témához illő festményekről.

Így talán nem túlzó azon állításunk, hogy van vonzódásunk a műalkotásokhoz. Sajnos léteznek kriminális kötődései a témának, ezért büntetőeljárás-jogászokként, kriminalistákként is van érdeklődésünk. Örömmel valljuk be, hogy nagyon erős muníciót kaptunk most a figyelmünkhöz, a mindennapi oktatáshoz. A Bendzsel Miklós, Emőd Péter és Kármán Gabriella szerkesztette Mútárgyhamisitás magyar szemmel. Ocsút a búzától címú, a Szellemi Tulajdon Nemzeti Hivatala, az Országos Kriminológiai Intézet és a Kieselbach Galéria közös, 2019-es kötetének 295 oldala nemcsak hasznos, érdekfeszítő, hanem szép is. Kimondhatjuk, szemet gyönyörködtető. Kívül-belül. Valódi műalkotás. Jó kézbe venni az ezüstösen fénylő textilhatású borítást. Igaz, tartani cseppet sem könnyü, hiszen a minőségi fehér és színes lapok súlyt adnak. Ahogyan a mondanivaló is.

Megtudhatjuk a múvészettörténetben, mútárgyvizsgálatokban gazdag tapasztalattal rendelkező tanulmányt íróktól (Barki Gergely, Bendzsel Miklós, Kovácsné Gőgös Ágota, Kieselbach Tamás, Lengyel László, Monos Péter, Sajó István, Váli Zsuzsanna), hogy a bőkezű mecénásokkal támogatott reneszánsz idején kezdték magukat egyéniségként, önálló, individualista szerzőként azonosítani a múalkotások (festmények, szobrok) büszke készítői. Gondoljunk csak a legnevesebbekre, Leonardóra, Michelangelóra, akik már szignójukkal, aláírásukkal látták el múveiket. Ezeknek olyan

\footnotetext{
Bendzsel Miklós - Emőd Péter - Kármán Gabriella: Mútárgyhamisítás magyar szemmel. Ocsút a búzától. Szellemi Tulajdon Nemzeti Hivatala - Országos Kriminológiai Intézet - Kieselbach Galéria, 2019.

2 Dr. habil. FENYVESI Csaba egyetemi tanár, Pécsi Tudományegyetem Állam-és Jogtudományi Kar Dr. habil. Csaba FENYVESI Professor, University of Pécs, Faculty of Law

https://orcid.org/0000-0002-5921-787; fenyvesi.csaba@ajk.pte.hu

3 Dr. HORVÁTH Orsolya PhD, óraadó tanár, Pécsi Tudományegyetem Állam- és Jogtudományi Kar Dr. Orsolya HORVÁTH PhD, part-time lecturer, University of Pécs, Faculty of Law

https://orcid.org/0000-0003-2570-2618; horvath.orsolya@pte.hu
} 
eszmei értékük volt már akkor is a művelt európai világban, hogy érdemes volt másolni őket. Később a ravasz, sokszor egyáltalán nem tehetségtelen, busás pénzre hajtó piktorok már önálló alkotásokat is létrehoztak a híres, virtuóz mesterek stílusában, illetve a meglévő vásznakon hajtottak végre változtatásokat. És ez igaz már a 19-20. századi magyar mesterművekre is (festményekre, grafikákra, szobrokra, szőnyegekre, bútorokra).

Hogy kik voltak ezek a kufár elkövetők és milyen furfangos módszereket alkalmaztak a gyanútlan, jóhiszemú, óvatlan vásárlók, alkalmanként kereskedők, múgyüjtők, galériák megtévesztésére, azt megtudhatja az Olvasó a kötet I. fejezetéből. Hogyan buktak meg, mik voltak a banánhéjak, illetve miként léptek és léphetünk fel velük és múvészi értékeink presztizsét romboló aktivitásukkal szemben intézményes eszközökkel, közöttük a joggal, azon belül is a büntetőjoggal, azt megismerhetjük a II. fejezetből Buzinkay Péter, Karsay Enikő, Kármán Gabriella, Kiss Zoltán Károly, Martos Gábor tollából. Közülük az Országos Kriminológiai Intézet tudományos főmunkatársa, Kármán Gabriella (PhD) - aki egyben a Hamisítás Elleni Nemzeti Testület Mútárgyhamisítás elleni munkacsoportjának vezetője - tükörtartását emelem ki. Bemutatja, elemzi a 2000-2012 közötti műtárgyhamisításokkal és hamis műtárgyak kereskedelmével elkövetett 133 csalási ügy nyomozási jellemzőit, bírósági ítéleteit. (Itt jegyezzük meg, hogy nagyságrendileg nem elhanyagolható esetkörről van szó, hiszen például Németországban az 1990-es évek elejétől az élen álló kábítószer-kereskedelem mögé sorakozott fel a hamis mútárgyak illegális piaca.)

Logikusan fut elénk a III. nagy fejezet, ami a műtárgyhamisítás elleni fellépés, az „örök játszma” kriminalisztikai, jogi eszközeit, a megelőzésre irányuló jövendő feladatcsokrot ecseteli. Emőd Péter, Farkas Krisztina, Kármán Gabriella és Németh Mónika ecsetvonásaiból képet kapunk a magyar Hamisítás Elleni Nemzeti Testület megalakulásáról, prevenciós szerepéről, valamint a német és olasz (témában illetékesként eljáró) hatóságok erőfeszítéseiről. Igazi csemege, művészeti, egyúttal bűnügyi gyöngyszem a Beltracchi-ügy aprólékos boncolgatása. Hogy ki volt egyáltalán a hírhedt Beltracchi, és mivel kábította el a világot, azt a Magyar Rendészet tisztelt olvasóinak kell kiderítenie, mégpedig a hiánypótló kötet kézbevételével, a fejezetrész gondos tanulmányozásával. Nem árulhatjuk el a választ, hiszen akkor egy valós krimi titkait tárnánk fel.

Azt viszont már most közzétesszük, hogy ebből a műből megismertünk számtalan szakkifejezést. Így például: atteszt, autentikáció, csalikép, dendrokronológia, festői receptúra, pentimentó, proveniencia, raglap, tisztító nyílás.

$\mathrm{A} z$ is világossá vált számunkra, hogy a rendszerváltásunk hozta magával a hazai mütárgy-kereskedelem és egyúttal a hamisítások (meghamisítások) élénkülését is, miután a festmények, szobrok, szőnyegek, bútorok piaca kinyílt, jelentős értékek, árak, pénzösszegek, külföldi és hazai befektetők és vastag bukszájú múkedvelők bukkantak fel.

A szakemberek felismerték hazánkban is, hogy széles körû, átlátható, pontos adatbázisokra, kriminalisztikai eszközöket és módszereket használó laborokra (elektronmikroszkóp, röntgendiffrakció, spektroszkópia, UV-lámpák stb.), a tisztességes résztvevők közötti folyamatos információcserére, cizellált, stíluskritikai, termé- 
szettudományos analízisben, festék-, fa-, lakk-, papír-, ragasztó-, vászonanyagokban, kormeghatározásokban is jártas ismeretekkel rendelkező szakértőkre, mélységi tudású, kiállításokkal, könyvekkel edzett szemű specialistákra, mindezek csapatmunkájára és minőségi egyetemi szakképzésre (és talán egy iránytűként szolgáló), módszertani levélre van szükség a hatékony felderítések, felismerések, kiszűrések érdekében. Ha mindez megvan, még akkor sem garantált a siker egy-egy műalkotás eredetének biztos megállapításához.

Tanulságos, egyúttal helytálló azon megállapítása is a szerzőknek, hogy: bizonyossággal csak azt lehet megállapítani, hogy a vizsgált mű nem attól ered, akinek vallják, hiszik, mondják. Azt, hogy valóban a szóban forgó szerzőtől (vagy mástól), azt bizonyossággal kimondani jelenleg nem lehet. (Feltehetően a jövőben sem.) „Olyan vizsgálat nincs, amelyik bizonyítja, hogy a mútárgy eredeti, csak olyan, amelyik kizárja." Ez a gondolat összecseng a kriminalisztikában alkalmazott bizonyítási kísérlet eredményével. Ott is a kizáró, a nemleges az értékes. A „megtörténhetett” megállapítás csak lehetőség, de nem bizonyosság.

Egy másik nyomozási cselekménnyel is találtunk párhuzamot az opusban. Éppen a mostani kutatási területünknél, a felismerésre bemutatásnál is felírhatjuk vörös krétás nagy betűkkel a hófehér falra figyelmeztetésként a jogalkalmazók számára: ami majdnem az, az nem az! ${ }^{5}$

A tanulmányfüzérből vesszük a zárógondolatunkat is, mintegy következő intelemként, felhívásként, örök feladatként a rendészetben, bűnügyekben dolgozó detektálóknak, megelőzőknek. Nem feledhetjük ugyanis, hogy mindannyiunk folyamatos feladata, felelőssége, hogy meg tudja különböztetni a pszeudót, a camouflage-t a valóditól, a konkolyt, a pelyvát, az ocsút a búzától.

\section{IRODALOMJEGYZÉK}

Bendzsel Miklós - Emőd Péter - Kármán Gabriella: Mútárgyhamisitás magyar szemmel. Ocsút a búzától. Szellemi Tulajdon Nemzeti Hivatala - Országos Kriminológiai Intézet - Kieselbach Galéria, 2019.

\footnotetext{
Bendzsel-Emőd-Kármán (2019) i. m. 116.

Bendzsel-Emőd-Kármán (2019) i. m. 39.
} 